\title{
Impedance Spectroscopy applied to the study of high dilutions of Lycopodium clavatum
}

\author{
Claudia Takano ${ }^{1}$, Adriana Ramos de Miranda² and Álvaro Vannucci ${ }^{3}$ \\ (1) College of Health Sciences of São Paulo - FACIS, SP, Brazil \\ (2) Institute of Physics Gleb Wataghin, University of Campinas, SP, Brazil \\ (3) Physics Institute, University of São Paulo, SP, Brazil
}

\begin{abstract}
Introduction: The Impedance spectroscopy [1] is a technique mainly used to characterize the electrical behavior of solids or liquids samples. This particular technique involves placing the sample of material under investigation between two electrodes (capacitor plates), applying an AC voltage and observing the resulting response across the spectrum of impedance by plotting the real part (Z') as a function of the imaginary part (Z") of the impedance. Alternatively, graphs of either the real or the imaginary parts of the impedance can be constructed as a function of the applied voltage frequency. Comparative measurements previously carried out by Miranda et al [2]. have demonstrated clear differences between the impedance values of high dilutions of lithium chloride $(\mathrm{LiCl})$ and the corresponding reference water samples (water which has undergone the same dinamization procedures but without the salt). In this paper the results obtained by applying the spectroscopy of impedance technique in high dilutions of Lycopodium clavatum - Lyc (from $15 \mathrm{cH}$ to $30 \mathrm{cH}$ ), in comparison to the reference waters, will be presented and discussed.
\end{abstract}

Aims: The objective of this work is to measure the impedance components of both high dilutions of Lycopodium clavatum and reference water samples in the frequency range of $100 \mathrm{~Hz}$ to $13 \mathrm{Mhz}$, using a successful protocol of sample preparation which has already been used before ${ }^{2}$. Details of the experimental set-up can be found elsewhere[3].

Methodology: Thirty samples of $L y c$ solutions and thirty reference water samples were produced using the same preparation and measuring protocol. Both groups of liquid samples were prepared for dynamizations ranging from $1 \mathrm{cH}$ to $30 \mathrm{cH}$, in accordance to the Hahnemanian dynamization method and following the practice suggested by the Brazilian Homeopathic Pharmacopeia. The Lyc solutions were specifically compared to the reference water samples in the potencies of $15 \mathrm{cH}, 18 \mathrm{cH}, 23 \mathrm{cH}$ and $30 \mathrm{cH}$. It is important to highlight here that all the Lyc solutions and the corresponding reference water samples measured were prepared from the same lot of initial distilled water and submitted to the same steps of dilution and succussion protocol ${ }^{3}$. Typically three impedance measurements were carried out for each investigated solution, starting with the highest potency. The sample holder (capacitor cell) used during the experiment was careful and systematically cleaned after each measurement.

Results: The results obtained show that by choosing either the real part (Z') or the imaginary component (Z') of the impedance, it is possible to clearly differentiate the Lyc solutions from the corresponding reference 
water samples, for the potencies $15 \mathrm{cH}, 18 \mathrm{cH}$ and $30 \mathrm{cH}$. For the potency $23 \mathrm{cH}$, however, this difference is not very significant, as it can be observed in Figure 1.

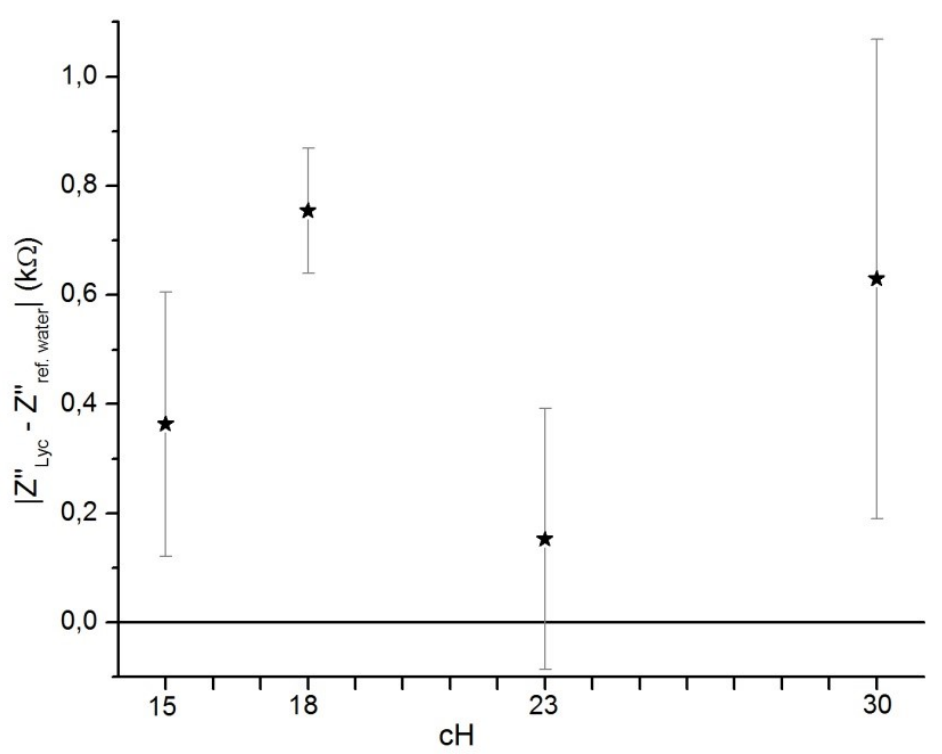

Figure.1: Modulus of the difference between the minimum of the Z" values of the $L y c$ solutions and the corresponding reference water samples.

Conclusion: Impedance spectroscopy has demonstrated itself to be a powerful and sensitive technique for the physical characterization of Lycopodium clavatum in high dilutions. The differences obtained for the $\mathrm{LiCl}$ dynamizations and the corresponding pure water samples are noteworthy. Also, the results exhibit a nonmonotonic behavior over the process of dynamization, indicating that the possibility of contamination during the samples manipulation can be ruled out.

\section{Bibliography:}

[1] MacDonald JR (ed), Impedance Spectroscopy - Emphasizing Solid Materials and Systems, John Wiley \& Sons, USA, 1987.

[2] Miranda AR, Vannucci A, Pontuschka WM, Impedance Spectroscopy of Water in Comparison to High Dilutions of Lithium Chloride, Material Research Innovation, accepted for publication in October 2011.

[3] Takano C, Characterization of high dilutions of Lycopodium clavatum by impedance spectroscopy in the frequency range of $20 \mathrm{~Hz}$ to $13 \mathrm{MHz}$ (in Portuguese), Monograph, College of Health Sciences of São Paulo (2009).

\section{Espectroscopia de Impedância aplicada ao estudo de soluções ultra diluídas de Lycopodium clavatum}

\section{RESUMO}

Introdução: A espectroscopia de impedância [1] é uma técnica amplamente utilizada para caracterizar o comportamento elétrico de materiais sólidos e líquidos. A técnica consiste em colocar a amostra do material 
sob investigação entre dois eletrodos (placas de um capacitor), aplicando uma tensão alternada, e observar a resposta resultante através do espectro de impedância - gráfico da parte real (Z') em função da parte imaginária (Z”) da impedância. A análise também pode ser feita através dos gráficos de Z’ e Z” em função da freqüência da tensão aplicada. Medidas realizadas anteriormente por A.R. Miranda et al [2] demonstraram diferenças significativas entre medidas de impedância de soluções ultra diluídas de cloreto de lítio (LiCl) e suas respectivas águas de referência (placebo - água submetida ao mesmo processo de dinamização que as soluções de $\mathrm{LiCl}$, sem inclusão do sal). O presente trabalho apresenta e discuti os resultados obtidos através da aplicação da técnica de espectroscopia de impedância em soluções ultra diluídas de Lycopodium clavatum $L y c$ (de $15 \mathrm{cH}$ a $30 \mathrm{cH})$ e suas respectivas águas de referência.

Objetivo: O objetivo principal deste trabalho é caracterizar fisicamente soluções ultra diluídas de Lycopodium clavatum e suas respectivas águas de referência através da técnica de espectroscopia de impedância, no intervalo de $100 \mathrm{~Hz}$ à $13 \mathrm{MHz}$, aplicando um protocolo previamente utilizado com sucesso ${ }^{2}$. Detalhes do protocolo experimental poderão ser encontrados em outros trabalhos [3].

Metodologia: Foram produzidas 30 amostras de Lyc e 30 amostras de água de referência, preparadas da $1 \mathrm{cH}$ até $30 \mathrm{cH}$, conforme método hahnemanianno - de acordo com a Farmacopéia Homeopática Brasileira. As soluções de $L y c$ foram comparadas com seus respectivos placebos (água de referência) nas potências $15 \mathrm{cH}$, $18 \mathrm{cH}, 23 \mathrm{cH}$ e $30 \mathrm{cH}$. É importante ressaltar que as soluções placebo foram preparadas a partir da mesma água que gerou as amostras de $L y c$, e submetidas às mesmas etapas de diluição e sucussão, obtendo-se assim uma referência para cada uma das amostras de $L y c$. As amostras foram medidas em triplicata, iniciando-se pela maior diluição, e executando a limpeza do porta-amostra (capacitor de placas paralelas) a cada medição.

Resultados: Os dados obtidos de Z', assim como de Z", mostram que é possível diferenciar amostras de $L y c$ das amostras placebo correspondentes, para as dinamizações $15 \mathrm{cH}, 18 \mathrm{cH}$ e $30 \mathrm{cH}$. Quanto a dinamização $23 \mathrm{cH}$ as diferenças não são significativas. Os resultados obtidos mostram, claramente, um comportamento não monotônico das soluções ultra diluídas no decorrer do processo de diluição e sucussão. Através da subtração dos valores de pico de Z" das soluções de Lyc e de sua respectiva água de referência, podemos observar a magnitude da diferença das soluções estudadas, assim como seu comportamento não monotônico, conforme mostrado na Fig.1.

Conclusão: Os dados obtidos confirmam o elevado potencial da técnica de espectroscopia de impedância, para análise e caracterização de soluções ultra diluídas de Lycopodium clavatum. O comportamento não monotônico observado afasta a possibilidade das diferenças encontradas estarem relacionadas com a presença de algum contaminante.

\section{(cc) EY-NC-ND Licensed to GIRI}

Support: authors declare that this study received no funding

Conflict of interest: authors declare there is no conflict of interest

Correspondence author: Adriana Ramos de Miranda, adrianam@ifi.unicamp.br

How to cite this article: Takano C, Miranda AR and Vannucci A. Impedance Spectroscopy applied to the study of high dilutions of Lycopodium clavatum. Int J High Dilution Res [online]. 2011 [cited YYYY Month dd]; 10(36): 101-103. Proceedings of the XXV GIRI Symposium and VIII CBFH; 2011 Sep 04-07; Foz do Iguaçu (Brazil). GIRI and ABFH; 2011; Available from: http://www.feg.unesp.br/ ojs/index.php/ijhdr/article/view/480/494 